\title{
KONSEP DIRI PADA REMAJA YANG MENGALAMI BULLYING
}

\author{
Galih Aditiya Wijayanto ${ }^{1}$, Eni Hidayati ${ }^{2}$ \\ Universitas Muhammadiyah Semarang ${ }^{1,2}$ \\ eni.hidayati82@gmail.com²
}

\begin{abstract}
ABSTRAK
Penelitian ini bertujuan untuk mengetahui bagaimana pengaruh perilaku bullying terhadap konsep diri pada remaja. Metode penelitian yang digunakan kuantitatif dengan pendekatan kausal-komparatif. Hasil penelitian menunjukan bahwa ada pengaruh bullying terhadap konsep diri pada remaja. Berdasarkan hasil uji $\mathrm{R}$ square diketahui bahwa bullying memiliki pengaruh sebesar $51,1 \%$ untuk menentukan konsep diri pada remaja, dan 48,9\% sisanya dipengaruhi oleh sesuatu yang tidak diteliti pada penelitian ini. Simpulan, semakin tinggi atau sering remaja dibully maka konsep dirinya akan semakin menurun. Semakin sering seseorang menjadi korban bullying maka akan semakin negatif konsep diri yang dimilikinya.
\end{abstract}

Kata Kunci: Bullying, Konsep Diri, Remaja

\section{ABSTRACT}

This study aims to determine how the influence of bullying behavior on self-concept in adolescents. The research method used is quantitative with a causal-comparative approach. The results showed that there was an effect of bullying on self-concept in adolescents. Based on the $R$ square test results, it is known that bullying has an impact of $51.1 \%$ to determine self-concept in adolescents, and the remaining $48.9 \%$ is influenced by something not examined in this study. In conclusion, the higher or often the teenager is bullied, the self-concept will decrease. The more often a person becomes a victim of bullying, the more negative his self-concept will be.

Keywords: Bullying, Self Concept, Youth

\section{PENDAHULUAN}

Kasus bullying di dunia oleh teman sekolah pada beberapa negara sangat tinggi. Pada tahun 2015 di Nepal angka bully mencapai 51\%. Tahun 2016 di Myanmar mencapai 50\% (WHO, 2017). KPAI mencatat korban bully yang terjadi di Indonesia sebanyak 26 ribu kasus sejak tahun 2011-2017 (KPAI, 2017).

Dunia pendidikan Indonesia masih banyak terjadi kasus perilaku kekerasan di sekolah baik antar murid, guru terhadap murid dan juga sebaliknya murid terhadap guru. Bullying merupakan salah satu perilaku kekerasan yang banyak terjadi di hampir seluruh sekolah di Indonesia. Pemalakan, pemukulan, pengejekan yang dilakukan kebanyakan senior terhadap juniornya maupun antar siswa disekolah disebut dengan bullying. Bullying di lingkungan sekolah, biasanya tidak terpantau oleh guru maupun orang dewasa lainnya. Fakta dilapangan, kebanyakan para remaja korban bullying enggan untuk mengatakan apa yang dialaminya kepada orang lain, termasuk guru. 
Remaja korban bullying seringkali menjadi depresi, cemas, melakukan tindakan ke arah menyakiti diri sendiri, eating disoders, dan gejala-gejala masalah fisik seperti sakit kepala, sakit perut, demam, dan sulit tidur (Khasanah et al., 2017).

Remaja korban bullying memiliki karakteristik tertentu yang menjadi ciri khas yang menjadikannya korban bullying, para korban cenderung berbeda dalam penampilan atau kebiasaan sehari-hari. Perbedaan latar belakang, etnik, keyakinan, ataupun budaya dalam lingkungan tersebut, yang menjadikannya sebagai kelompok yang minoritas dalam lingkungan. Individu atau remaja yang mempunyai bakat atau kemampuan yang istimewa sering juga menjadi korban perilaku bullying. Keterbatasan kemampuan remaja juga dapat menjadikan perilaku bullying terjadi terhadapnya. Hal tersebut merupakan faktor eksternal pada korban bullying. Faktor internal pada korban bullying salah satunya adalah konsep diri yang negatif pada dirinya (Herdyanti \& Margaretha, 2017).

Konsep diri negatif akan mempengaruhi perilaku remaja melakukan tindakan yang kurang baik, sebaliknya konsep diri positif akan mempengaruhi perilaku remaja menjadi positif. Konsep diri juga mempengaruhi dalam pembentukan kepribadian individu, konsep diri pada individu menjadikannya makhluk yang berbeda dan unik, dimana masing-masing individu memiliki pemahaman terhadap dirinya sendiri yang diyakini sebagai bagian dari dirinya. Remaja korban bullying cenderung memiliki konsep diri yang negatif, hal ini mengakibatkan korban bullying cenderung bersikap tidak menyukai dan tidak menerima keadaan dirinya sehingga rasa percaya diri, dan harga diri akan berkurang serta dapat menghambat interaksi sosial (Rilla, 2018). Permasalahan pada remaja tersebut tentu memerlukan penanganan yang menyeluruh dan terintegrasi dengan melibatkan semua unsur (Sartika et al., 2021).

Berdasarkan studi pendahuluan yang dilakukan peneliti dari 30 sample siswa yang dipilih secara ramdom dan diwawancarai, 22 siswa belum mengetahui bentuk-bentuk bullying dan cara menyikapinya dan sisanya 8 siswa hanya mengetahui bentuk-bentuk bullying. 14 siswa mengatakan pernah melihat temannya dibully, 9 siswa mengatakan pernah mendapatkan bullying dari siswa lain, dan 7 siswa belum pernah mendapatkan ataupun melakukan bullying.

Penelitian sebelumnya sudah pernah dilakukan untukmelihat bagaimana konsep diri remaja yang mengalami bullying, namun masih perlu dilakukan penelitian lebih lanjut terkait permasalahan bullying ini karena kasus bullying masih banyak terjadi.

\section{METODE PENELITIAN}

Penelitian yang akan dilaksanakan oleh peneliti menggunakan metode kuantitatif dengan pendekatan kausal - komparatif. Dalam penelitian ini dilihat sejauh mana satu variabel bebas menentukan variabel terikat pada subjek penelitian. Pada penelitian ini dilakukan untuk melihat sejauh mana variabel bullying mempengaruhi konsep diri pada remaja.

Populasi pada penelitian yang akan dilakukan adalah siswa kelas VIII sebanyak 255 siswa. Cara pengambilan sampel yang digunakan dalam penelitian ini adalah menggunakan purposive sampling dengan besar sampel yang digunakan dalam penelitian ini dihitung menggunakan metode slovin yaitu 156 responden. Penelitian ini dilakukan dengan alamat di Jl. Kedungmundu, Kec. Tembalang, Kota Semarang, Provinsi Jawa Tengah. 
Alat pengumpulan data berupa kuisioner yang pertama menggunakan kuisioner MPVS (Multidimensional Peer-Victimization Scale). Berjumlah 16 item. Kriteria Penyekoran, $0=$ Tidak sama sekali, $1=$ Sekali, $2=$ Lebih dari sekali. Kuisioner yang kedua adalah Tennesse Self Concept Scale (TSCS) Instrument yang digunakan untuk mengukur tingkat konsep diri dengan kuisioner TSCS berjumlah 100 buah, 45 item favorable dan 45 item unfavorable, serta 10 item untuk mengukur keterbukaan individu dalam menjawab pernyataan skala konsep diri. Kriteria penyekoran alternative jawaban butir positif: $1=(\mathrm{STS})$ Sangat tidak sesuai, $2=(\mathrm{TS})$ Tidak Sesuai, $3=(\mathrm{TP})$ tidak pasti, $4=(\mathrm{S})$ Sesuai, $5=(\mathrm{SS})$ Sangat Sesuai dan pernyataan negative kebalikannya.

\section{HASIL PENELITIAN}

Tabel. 1

Kategori Skor Perilaku Bullying yang Dialami Responden

\begin{tabular}{cccc}
\hline & & Jumlah & Persen $(\%)$ \\
\hline \multirow{4}{*}{ Valid } & Rendah & 89 & 57.1 \\
& Sedang & 52 & 33.3 \\
& Tinggi & 15 & 9.6 \\
& Total & 156 & 100.0 \\
\hline
\end{tabular}

Berdasarkan tabel 1 menunjukan bahwa jumlah skor perilaku bullying yang dialami responden mayoritas dengan kategori bullying rendah yaitu berjumlah 89 orang $(57.1 \%)$.

Tabel. 2

Kategori Skor Konsep Diri Responden

\begin{tabular}{lcc}
\hline & Jumlah & Persen $(\%)$ \\
\hline Sangat rendah & 0 & 0 \\
Rendah & 24 & 15.4 \\
Sedang & 75 & 48.1 \\
Tinggi & 57 & 36.5 \\
Sangat tinggi & 0 & 0 \\
\hline Total & 156 & 100.0 \\
\hline
\end{tabular}

Berdasarkan tabel 2 menunjukan bahwa jumlah skor konsep diri yang diperoleh oleh respondenmayoritas masuk kedalam kategori tinggi berjumlah 57 orang (36.5\%).

Tabel. 3

Kategori Bullying * Kategori Konsep Diri Crosstabulation

\begin{tabular}{llrrrr}
\hline & & \multicolumn{2}{c}{ Kategori Konsep Diri } & \multicolumn{2}{c}{ Total } \\
\hline \multirow{2}{*}{ Kategori Bullying } & Rendah & \multicolumn{2}{c}{ Sedang } & Tinggi & 89 \\
& Sedang & 1 & 34 & 54 & 52 \\
& Tinggi & 12 & 37 & 3 & 15 \\
\hline Total & 11 & 4 & 0 & 156 \\
\hline
\end{tabular}


Berdasarkan tabel 3 menunjukan bahwa responden dengan kategori bullying rendah lebih banyak memiliki konsep diri yang tinggi yaitu sebanyak 54 orang, konsep diri sedang 34 orang, dan konsep diri rendah 1 orang. Kategori bullying sedang yang memiliki konsep diri tinggi sebanyak 3 orang, konsep diri sedang 37 orang, dan konsep diri rendah 12 orang. Sedangkan kategori bullying tinggi yang memiliki skor konsep diri tinggi tidak ada, konsep diri sedang 4 orang dan konsep diri rendah 11 orang.

Tabel. 4

Analisis Pengaruh Bullying terhadap

Konsep Diri pada Remaja

\begin{tabular}{|c|c|c|c|c|c|}
\hline \multicolumn{6}{|c|}{ Unstandardized Coefficients } \\
\hline & & $\mathrm{B}$ & Std. Error & $\mathrm{t}$ & Sig. \\
\hline \multirow[t]{2}{*}{1} & (Constant) & 354.350 & 3.512 & 100.899 & .000 \\
\hline & Total Skor Bullying & -3.321 & .262 & -12.689 & .000 \\
\hline
\end{tabular}

Berdasarkan tabel 4 menunjukkan bahwa $(p$ value $)=0,000(\mathrm{p}<0,05)$ artinya ada pengaruh bullying terhadap konsep diri. Koefisien untuk persamaan nilai pengaruh variabel bullying terhadap konsep diri adalah sebesar -3,321, sementara nilai konstantanya adalah 354.350. Artinya setiap peningkatan skor bullying akan menurunkan skor konsep diri sebesar $-3,321$. Koefisien regresi tersebut adalah negatif sehingga dapat disimpulkan bahwa pengaruh bullying terhadap konsep diri adalah negatif.

\section{PEMBAHASAN}

Pada penelitian ini dari 156 responden jumlah responden mayoritas laki-laki yaitu sebanyak 64 orang (41\%) serta mayoritas usia 14 tahun yaitu sebanyak 93 orang (59.6\%). Penelitian yang dilakukan Kholifah (2019) kasus bullying di sekolah dapat terjadi di semua jenjang pendidikan, mulai dari pendidikan dasar hingga pendidikan tinggi. Pada penelitian ini, responden yang dicakup berada dalam jenjang umur antara 15-19 tahun, dengan usia terbanyak adalah 17 tahun sebesar 39,3\% (22 orang).

Pada rentang usia tersebut, responden tergolong sebagai remaja yang sedang mengalami masa peralihan dimana responden sudah tidak layak diperlakukan sebagai anak kecil, namun pertumbuhan fisik dan mentalnya pun belum layak dianggap dewasa. Pada fase ini remaja mengalami masa storm and stress, dimana kerap terjadi pergolakan emosi yang labil dengan diiringi pertumbuhan fisik yang pesat, serta perkembangan psikis yang sangat rentan terpengaruh oleh lingkungan. Hasil tersebut selaras dengan penelitian Marela (2017) bahwa remaja SMA rentan terhadap kasus bullying dengan angka kejadian mencapai $49 \%$

Banyaknya tindakan bullying pada remaja dapat berdampak buruk bagi korban, pelaku, maupun yang menyaksikan tindakan bullying tersebut. Tidak hanya trauma secara fisik namun juga dapat menyebabkan trauma secara mental psikologis, salah satunya bisa mempengaruhi konsep diri pada remaja.

Berdasarkan hasil uji analisis data menunjukan bahwa ada pengaruh bullying terhadap konsep diri pada remaja. Sedangkan nilai koefisien untuk persamaan nilai pengaruh variabel bullying terhadap konsep diri adalah sebesar -3,321, sementara nilai konstantanya adalah 354.350. Artinya setiap terjadi peningkatan skor bullying akan menurunkan skor konsep diri sebesar $-3,321$. Koefisien regresi tersebut adalah negatif sehingga dapat disimpulkan bahwa pengaruh bullying terhadap konsep diri adalah 
negatif. Analisis regresi menghasilkan Rsquare sebesar 0.511 , artinya bahwa bullying memiliki pengaruh sebesar $51,1 \%$ untuk menentukan konsep diri pada remaja.

Hasil penelitian Kholifah (2019) menunjukkan bahwa bullying memiliki pengaruh terhadap konsep diri remaja $(\mathrm{r}=0,242)$, dengan pengaruh sebesar 5,8\% ( $\mathrm{R}$ Square $=$ 0,058). Hal ini berarti konsep diri dipengaruhi sebesar $94,2 \%$ oleh variabel lain yang tidak diteliti. Sejalan dengan penelitian Lestari (2018) yang menunjukkan bahwa terdapat pengaruh negatif dan signifikan konsep diri terhadap perilaku bullying siswa dengan koefisien beta $(\beta)=-0272$, dan nilai t hitung $>$ t tabel $(2,571>-0211)$ dan nilai dari $\mathrm{p}=0,012(\mathrm{p}<0,05)$.

Sejalan dengan penelitian Nubli et al., (2019) menunjukkan bahwa hasil analisa univariat diperoleh sebagian besar konsep diri yang positif pada remaja berjumlah 178 orang $(53,5 \%)$, kemampuan menghadapi perilaku bullying positif berjumlah 180 orang $(54,1 \%)$, hubungan konsep diri pada remaja terhadap kemampuan menghadapi perilaku bullying di SMKN 2 Pekanbaru ( $p$ value $=0,000<0,05$ ). Kesimpulan pada penelitian ini diketahui bahwa ada hubungan yang signifikan antara konsep diri pada remaja terhadap kemampuan menghadapi perilaku bullying di SMKN 2 Pekanbaru

Sejalan dengan penelitian Aditya \& Rusmawati (2018) adanya hubungan negatif dan signifikan antara konsep diri dengan intensi bullying ( $r x y=-0,390 ; p=0,000$ ). Semakin rendah konsep diri maka semakin tinggi siswa akan semakin tinggi melakukan bullying dan sebaliknya. Konsep diri dalam penelitian memberikan sumbangan efektif sebesar 15,2\% terhadap intensi bullying, 84,2\% dipengaruhi oleh faktor lain yang tidak bisa diungkapkan dalam penelitian ini. Penelitian yang dilakukan Rilla (2019) juga menunjukkan bahwa ada hubungan yang signifikan antara bullying dengan konsep diri remaja.

Responden dengan kategori bullying rendah akan memiliki konsep diri yang tinggi yaitu sebanyak 54 orang, konsep diri sedang 34 orang, dan konsep diri rendah 1 orang. Kategori bullying sedang yang memiliki konsep diri tinggi sebanyak 3 orang, konsep diri sedang 37 orang, dan konsep diri rendah 12 orang. Sedangkan kategori bullying tinggi yang memiliki skor konsep diri tinggi tidak ada, konsep diri sedang 4 orang dan konsep diri rendah 11 orang. Hal ini berarti semakin tinggi atau sering remaja dibully maka konsep dirinya akan semakin menurun, begitu juga sebaliknya semakin rendah atau jarang remaja dibully maka konsep dirinya akan tinggi.

Penelitian yang dilakukan Lestari \& Liyanovitasari (2020) menunjukkan bahwa Konsep Diri pada remaja yang pernah mengalami bullying didapatkan bahwa jumlah yang mempunyai konsep diri positif dan negatif hampir seimbang, yaitu yang memiliki konsep diri positif sebanyak $45(51,1 \%)$ dan yang memiliki konsep diri negative sebanyak $43(48,9 \%)$.

Hal ini menandakan bahwa begitu besar dampak buruk bullying terhadap konsep diri pada remaja dimana pada masa remaja konsep diri individu masih dalam proses perkembangan. Apabila dalam masa perkembangannya remaja sering dibully atau sering menjadi korban bully bukan tidak mungkin remaja tersebut tumbuh menjadi individu yang mempunyai konsep diri yang negatif.

Hal tersebut selaras dengan penelitian Zakiyah et al., (2017) menjelaskan bahwa perilaku bullying memiliki dampak dalam masalah kesehatan baik secara fisik (seperti sakit kepala, sakit perut dan ketegangan otot, rasa tidak aman saat berada di lingkungan sekolah, dan penurunan semangat belajar dan prestasi akademis) maupun mental (seperti depresi, kegelisahan dan masalah tidur yang mungkin akan terbawa hingga dewasa). 
Konsep diri bagi remaja akan menentukan sikap dan perilaku remaja. Dalam pengembangan konsep diri remaja ada hal yang tidak boleh di abaikan yaitu proses internalisasi nilai - nilai yang dapat membentuk konsep diri pada remaja yang positif dan kearah yang dapat mendewasakan diri. Seseorang yang mempunyai konsep diri yang positif cenderung mendorong sikap optimis dan percaya diri yang kuat untuk menghadapi situasi apa saja di luar diri individu, namun sebaliknya konsep diri negatif akan menimbulkan rasa tidak percaya diri dan ini dapat mengundang kompensasi dengan bertindak agresif kepada obyek-obyek yang ada di sekitar diri individu yang bersangkutan, yang di landasi oleh rasa ketidak berdayaan yang berlebihan (Lestari \& Liyanovitasari, 2020).

Penelitian Nubli et al., (2019) berpendapat perilaku bullying ini didasari oleh sebagian besar konsep diri yang baik sehingga memiliki kemampuan yang baik pula dalam menghadapi perilaku bullying yang diterima. Selanjutnya Nubli menjelaskan bahwa untuk pernyataan konsep diri pada item harga diri tentang merasa malu ketika berbicara didepan umum menunjukan hasil negatif yang cenderung lebih tinggi dari pernyataan konsep diri lainnya. Pernyataan kemampuan menghadapi perilaku bullying pada item kontak fisik secara langsung menunjukan hasil negatif yang cenderung lebih tinggi dari pernyataan tentang kemampuan menghadapi perilaku bullying lainnya.

\section{SIMPULAN}

Kejadian bullying yang terjadi termasuk dalam kategori bullying tinggi. Kebanyakan bullying dilakukan oleh siswa laki-laki dibandingkan siswa perempuan, tetapi bullying oleh siswa perempuan juga masih terjadi. Hampir sebagian besar konsep diri remaja termasuk dalam konsep diri sedang sampai tinggi, dan hanya beberapa yang memiliki konsep diri rendah. Terdapat pengaruh negatif dari bullying terhadap konsep diri, dimana setiap peningkatan skor bullying akan menurunkan skor konsep diri responden. Hal ini berarti semakin tinggi atau sering remaja dibully maka konsep dirinya akan semakin menurun. Penelitian ini juga menyimpulkan bahwa semakin sering seseorang menjadi korban bullying maka akan semakin negatif konsep diri yang dimilikinya.

\section{SARAN}

Dari hasil penelitian ini diharapkan dapat dijadikan masukan untuk pemerintah terkait membuat kebijakan-kebijakan ataupun program guna meningkatkan usaha preventif untuk mencegah terjadinya bullying dilingkungan pendidikan yang melibatkan guru-guru terkait, maupun pemerhati remaja. Hasil dari penelitian ini juga diharapkan dapat menambah wawasan, ilmu pengetahuan, maupun referensi dalam ilmu keperawatan jiwa khususnya dalam mencegah terjadinya kasus-kasus bullying yang terjadi baik dilingkungan pendidikan maupun masyarakat. Dari penelitian ini penulis berharap akan menjadi data dasar untuk peneliti-peneliti selanjutnya yang akan meneliti lebih jauh tentang pengaruh bullying terhadap konsep diri dengan metode-metode yang lainnya. 


\section{DAFTAR PUSTAKA}

Aditya, V., \& Rusmawati, D. (2018). Hubungan antara Konsep Diri dengan Intensi Bullying pada Siswa SMA N 1 Purbalingga. Empati, 7(3), 252-258. https://ejournal3.undip.ac.id/index.php/empati/article/download/21858/20142

Herdyanti, F., \& Margaretha, M. (2017). Hubungan antara Konsep Diri dengan Kecenderungan menjadi Korban Bullying pada Remaja Awal. Jurnal Psikologi Undip, 15(2), 92. https://doi.org/10.14710/jpu.15.2.92-98

Khasanah, A. N., Damayanti, T., \& Sirodj, D. A. N. (2017). Gambaran Negative Automatic Thoughts pada Remaja Korban Bullying di Sekolah Menengah Pertama Kota Bandung. Psympathic: Jurnal Ilmiah Psikologi, 4(2), 239-250. https://doi.org/10.15575/psy.v4i2.1698

Kholifah, S. (2019). Pengaruh Bullying terhadap Konsep Diri Remaja di SMK Kesehatan Kendedes Malang. Jurnal Kesehatan Mesencephalon, 5(2), 100-106. https://doi.org/10.36053/mesencephalon.v5i2.145

KPAI. (2017). KPAI Terima Aduan 26 Ribu Kasus Bully Selama 2011-2017. http://www.kpai.go.id/berita/kpai-terima-aduan-26-ribu-kasus-bully-selama-20112017/

Lestari, P., \& Liyanovitasari, L. (2020). Konsep Diri Remaja yang Mengalami Bullying. Jurnal Keperawatan Terpadu (Integrated Nursing Journal), 2(1), 40. https://doi.org/10.32807/jkt.v2i1.45

Lestari, W. O. (2018). Pengaruh Konsep Diri dan Konformitas terhadap Perilaku Perundungan (Siswa SMP Negeri 27 Samarinda). Psikoborneo, 6(3), 690. http://ejournals.unmul.ac.id/index.php/psikoneo/article/view/4662

Marela, G. (2017). Bullying Verbal Menyebabkan Depresi pada Remaja SMA di Kota Yogyakarta. Bkm Journal of Community Medicine and Public Health, 33(1), 4348. file:///C:/Users/ASUS/Downloads/8183-83620-1-PB (1).pdf

Nubli, M. H., Marni, E., \& Anggreny, Y. (2019). Hubungan Konsep Diri pada Remaja terhadap Kemampuan Menghadapi Perilaku Bullying di SMKN 2 Pekanbaru. Jurnal Ners Indonesia, 9(1), 51. https://doi.org/10.31258/jni.9.1.51-58

Rilla, E. V. (2018). Hubungan Bullying dengan Konsep Diri Remaja di SMP Negeri 5 Garut Tahun 2017. Jurnal Ilmu Kesehatan Bhakti Husada: Health Sciences Journal, 9(2), 66-74. https://doi.org/10.34305/jikbh.v9i2.70

Rilla, E. V. (2019). The Correlation Between Bullying and Adolescent Self Concept Junior High School of Garut. Tajungpura Nursing Jurnal, 1(1), 1-12. https://jurnal.untan.ac.id/index.php/TNJ/article/view/38331

Sartika, A., Oktarianita, O., \& Padila, P. (2021). Penyuluhan terhadap Pengetahuan Remaja tentang PKPR. Journal of Telenursing (JOTING), 3(1), 171-176. https://doi.org/https://doi.org/https://doi.org/10.31539/joting.v3i1.2192

WHO. (2017). Mental Health Status of Adolescents in SouthEast Asia: Evidence for Action. http://apps.who.int/iris/bitstream/handle/10665/254982/9789290225737eng.pdf; jsessionid=E212548CDFABCF58B308C2D731638EF5? sequence $=1$

Zakiyah, E. Z., Humaedi, S., \& Santoso, M. B. (2017). Faktor yang Mempengaruhi Remaja dalam Melakukan Bullying. Prosiding Penelitian dan Pengabdian Kepada Masyarakat, 4(2), 324-330. https://doi.org/10.24198/jppm.v4i2.14352 